\title{
The Potential to Reduce Pollutant Emissions from Individual Household Sector by Involving Citizens as Project Stockholders
}

\author{
By Małgorzata Pietras-Szewczyk ${ }^{1}$
}

\begin{abstract}
Atmospheric pollutants come from many sources, mainly from industry and transport as well as from households. Each sector is characterized by different specificity that concerns both the volume of emissions and the type of pollutants emitted. Each of them has also different potential to reduce the load of emissions. The purpose of this article is to show the role and potential of individual households in the fight to improve air quality. The article also aims at showing that by raising public awareness and changing habits of individual users of central heating installations, it is possible to reduce the amount of pollutants emitted from this sector. An important part of the work is a summary of a survey conducted among 150 residents of Wroclaw. The study entitled Awareness of residents of the city of Wroclaw about the sources of atmospheric pollution contained 27 questions regarding general knowledge and air quality in Wroclaw.
\end{abstract}

Keywords: Environmental management, air quality, air pollutants, urban areas

\section{Introduction}

In recent years the problem of poor air quality in Poland has become an issue that not only catches the attention of experts, but also of media and society. Despite the high interest in the subject, public awareness is still low. Residents of cities and villages interested in the issue of air quality are reluctant to engage in activities aimed at improving air quality. At the same time, society expects actions from the government and selfgovernments.

The role of society in effective air quality management and its improvement is enormous; individual heat sources (home furnaces), passenger cars, and the structure of energy consumption are important factors affecting air quality (Pietras 2012, Pietras-Szewczyk 2017). Therefore, government and self-government programs aimed at air quality improvement have little chance of success without public commitment.

Public involvement in activities of the authorities is possible by changing the approach to project management in sectors related to environmental protection. The traditional approach, in which decision-makers issue administrative orders or make decisions, results in dead letters on environmental protection functioning in Polish law. The project approach allows for involving society in the projects implemented as a stakeholder. Such a methodology allows for recognizing the needs and fears of society as well as analyzing the threats posed by society. Thanks to the management of stakeholders, their negative 
impact on the project results can be significantly reduced.

\section{Sources of Atmospheric Pollution Emissions}

In public awareness of Polish society, the myth of industry as the main source of atmospheric pollution is well-established. In recent years, due to Poland's international commitments and related legislative activities as well as industry's adjustment to stringent standards, the importance of industry in emissions has considerably decreased. Emissions of pollutants from organized industrial sources have decreased, mainly due to the use of modern purification technologies and technical parameters of emissions (Zwoździak 2017).

What is more, according to the report by McKinley \& Company entitled Assessment of greenhouse gas emission reduction potential in Poland by 2030 (McKinley \& Company 2009) the decrease in total emissions in Poland is mainly due to changes in industry; apart from changes in applied technologies, the authors also indicate a reduction in the number of production plants in Poland, which took place during the period of political transformation. The report presents historical changes in emissions of individual pollutants and proposes actions to limit the growth of the emission intensity of the Polish economy.

The results of air quality control performed by Voivodeship Inspectorates of Environmental Protection indicate that the main pollutants present in the air, especially in large cities, are particulate matter and benzo[a]pyrene. The report of the National Center for Emissions (Management Institute of Environmental Protection - National Research Institute 2015a) and the Institute of Environmental Protection - National Research Institute (Management Institute of Environmental Protection - National Research Institute 2015b) includes emissions reports on air pollution taking into consideration statements for the United Nations Convention on Long-Range Transboundary Transport of Air Pollution (LRTAP) and for national statistics and European Union requirements. Summary of emissions nationwide covered the following pollutants and their groups:

- sulfur dioxide, nitrogen oxides, ammonia, carbon monoxide

- particulate matter (total- TSP, and fractions: PM10 and PM2.5)

- heavy metals (including metals mandatory reported to UNECE/EMEP: cadmium, mercury and lead; and reported so far on a voluntary basis: arsenic, chromium, zinc, copper and nickel)

- non-methane volatile organic compounds

- persistent organic pollutants - POPs (including dioxins and furans, polychlorinated biphenyls, hexachlorobenzene, benzo[a]pyrene and three other polycyclic aromatic hydrocarbons - PAHs).

The report presents the emission levels of total dust between 2012 and 2013. The emission calculated for 2013 is slightly higher (by approx. 0.02\%) compared to 2012. The increase in dust emissions in households is caused by greater consumption of hard coal (Management Institute of Environmental Protection - National Research Institute 2015a). In addition to total dust emissions, PM10 and PM2.5 emissions were also estimated. There was a slight increase in this case as well. The increase in national emissions of PM10 and 
PM2.5 is mainly due to the higher hard coal consumption in households. To a large extent it is burning of fossil raw materials such as hard coal in furnaces. Part of this emission comes from individual households, i.e. form central heating installations. In case of total dust, $40.3 \%$ of pollutants come from non-industrial combustion processes, $50.4 \%$ of PM10 particulate matter and $51.2 \%$ of PM2.5 come from the non-industrial sector. This means that half of the particulate matter emitted into the atmosphere comes from a sector other than industry, energy production or transport. Such a structure of emission of dust, to the largest extent responsible for the creation of smog, indicates huge potential to reduce the size of air pollution among users of individual heating installations

\section{The Potential of Individual Households}

\subsection{Public awareness of sources of emission of atmospheric pollution}

In order to test the knowledge of the inhabitants of Wroclaw, a survey on Awareness of residents of the city of Wroclaw about the sources of atmospheric pollution (Zakrzewski 2019) was conducted. 150 people completed the questionnaire. The study comprised 27 questions regarding general knowledge and air quality in Wroclaw. The survey was conducted entirely online. $41.3 \%$ of respondents were female and $58.7 \%$ male; $51.3 \%$ of respondents have higher education, $44.7 \%$ pointed to secondary education, $4 \%$ to vocational, and none of respondents was of primary education. The age groups of respondents were as follows: between 18 and 35 years old - 84\%, between 35 and 55 years old- $10 \%$ and $>55$ years old $-6 \%$.

The inhabitants of Wroclaw point out to air quality as an important element of life, along with safety. Answering the following question: What pollutants are the most harmful to the human body?, the inhabitants of Wroclaw replied that it is pollution from home heating. This answer was indicated by $50 \%$ of respondents. This choice was followed by industrial air pollution - $19.3 \%$, car fumes - 14.7\%, contamination of surface water by sewage $-8.7 \%$, and poor quality drinking water $-7.3 \%$. Answers marked as others were indicated by $4 \%$ of respondents. All of the above answers are correct due to the fact that each of them has the negative impact on the environment.

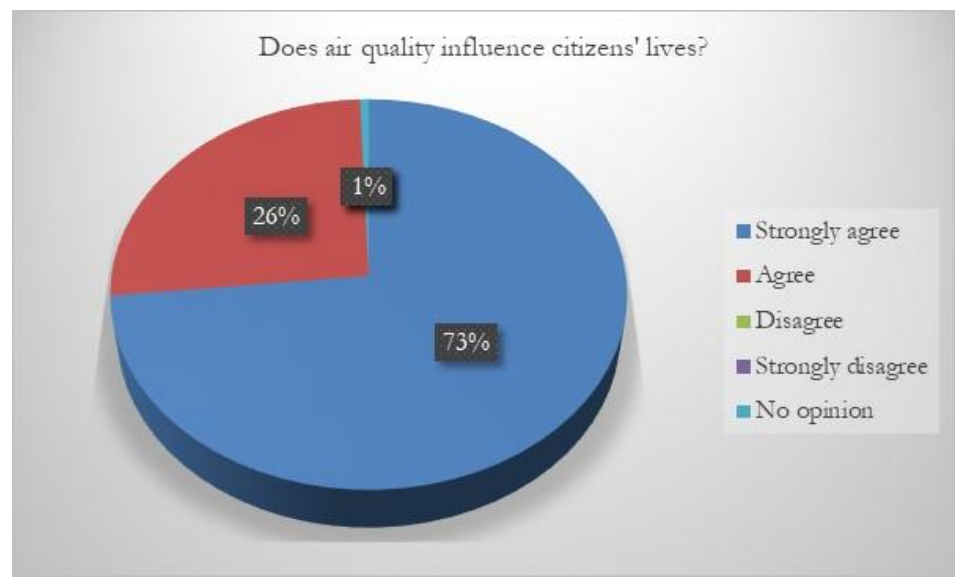

Fig. 1: One of study question: Does air quality influence citizens' lives? 


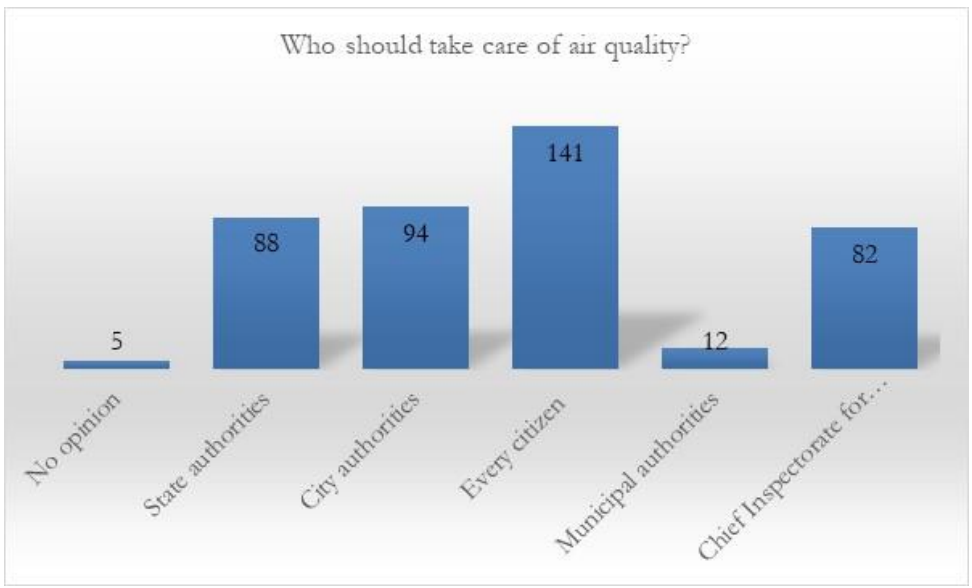

Fig. 2: One of study question: Who should take care of air quality? (Multiple choice question).

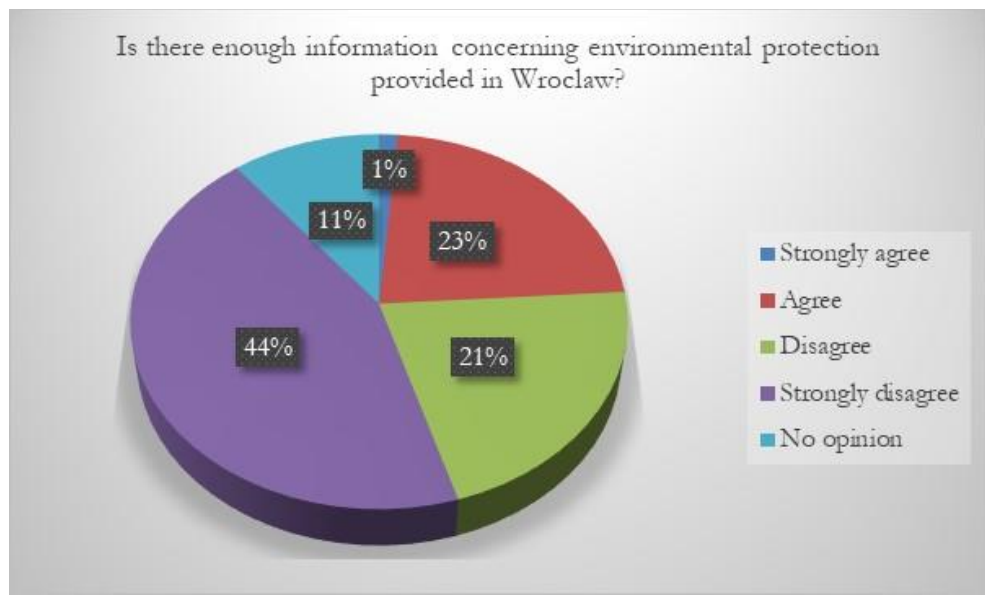

Fig. 3: One of study question: Is there enough information concerning environmental protection provided in Wroclaw?

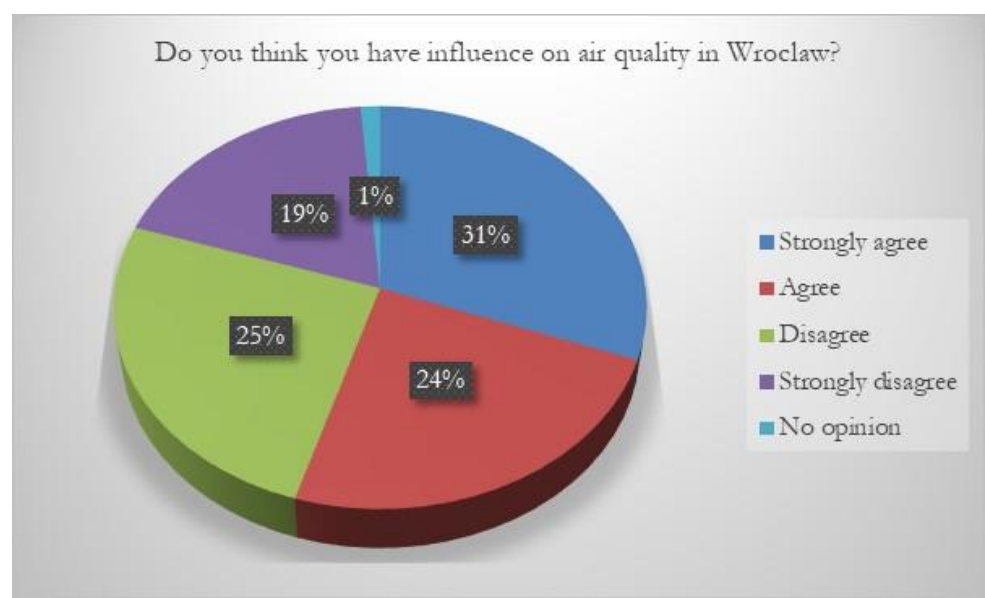

Fig. 4: One of study question: Do you think you have influence on air quality in Wroclaw? 
The results of the survey presented in the charts above show that the inhabitants of Wroclaw are aware of the impact of pollution on health. At the same time, they are aware of the fact that city dwellers themselves have the impact on of air quality. This is a very promising attitude that can become the basis for programs aimed at improving air quality in the city.

\subsection{Energy consumption and emission of pollutants from the household sector}

Individual customers, in particular households, constitute a significant group among consumers of hard coal, natural gas and heat. In 2016 households used 9,750 thousand metric tons of hard coal (Central Statistical Office 2016a). Consumption of this raw material by individual users of central heating installations exceeds that of professional heating plants, and in case of some voivodeships, also power plants and power stations Lubusz Voivodeship. This means that a large part of coal consumed in Poland goes to boilers working in individual households. Apart from coal, households also use natural gas, wood, heating oil, and district heating. The latter one concerns mainly multi-family housing.

Of 5,542,565 residential buildings, 3,940,647 are equipped with individual central heating installations (Table 1). The number of installations and the structure of fuel consumption in Polish homes unambiguously indicates huge potential to reduce the amount of pollutants emitted by changing the fuel or replacing the heat source with a more effective device.

Table 1: Buildings according to central heating installation and building type

\begin{tabular}{|c|c|c|c|c|c|c|c|c|}
\hline \multicolumn{2}{|c|}{ SPECIFICATIO } & \multirow[t]{3}{*}{ Total } & \multicolumn{6}{|c|}{ Central heating } \\
\hline \multirow{2}{*}{\multicolumn{2}{|c|}{$\begin{array}{l}\text { b- buildings } \\
\text { a- apartments } \\
\text { s- useful floor space } \\
{\left[\mathrm{m}^{2}\right]} \\
\mathrm{p} \text { - population }\end{array}$}} & & \multicolumn{4}{|c|}{ in a building } & \multirow[b]{2}{*}{ 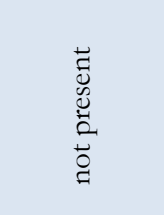 } & \multirow[b]{2}{*}{ 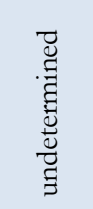 } \\
\hline & & & 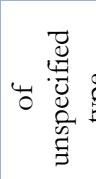 & 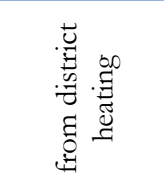 & 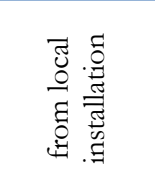 & 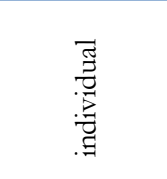 & & \\
\hline \multirow{4}{*}{$\begin{array}{l}{ }^{-1} \\
\stackrel{1}{-1} \\
\overrightarrow{2}\end{array}$} & b & $5,567,562$ & 1,421 & 317,334 & 26,507 & $3,952,476$ & $1,267,222$ & 2,602 \\
\hline & $\mathrm{a}$ & $13,009,046$ & 2,275 & $5,896,341$ & 334,064 & $4,861,629$ & $1,911,473$ & 3,264 \\
\hline & $\mathrm{s}$ & $912,323,599$ & 21,069 & 304107054 & $17,920,223$ & $473,342,555$ & 116,711783 & 25,915 \\
\hline & $\mathrm{p}$ & $38,121,369$ & 3,867 & $13,997,289$ & 775,502 & $17,767,554$ & $5,568,712$ & 8,445 \\
\hline \multirow{4}{*}{ 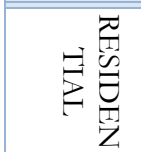 } & $\mathrm{b}$ & $5,542,565$ & - & 314,548 & 24,388 & $3,940,647$ & $1,262,982$ & - \\
\hline & $\mathrm{a}$ & $12,960,543$ & - & $5,885,533$ & 327,592 & $4,843,103$ & $1,904,315$ & - \\
\hline & $\mathrm{s}$ & $909,368,905$ & - & $303,581,653$ & $17,585,958$ & $471,829,033$ & $116,372,261$ & - \\
\hline & $\mathrm{p}$ & $38,005,676$ & - & $13,974,527$ & 760,688 & $17,716,867$ & $5,553,594$ & - \\
\hline
\end{tabular}

Knowing the number of central heating installations and the type of fuel being consumed, estimating the volume of emissions from the residential building sector should not cause any problems. The amount of this emission depends on the type of fuel, its consumption, fuel parameters such as calorific value, ash content, sulfur content, and the efficiency of the installation. In the simplest way, emissions can be determined using the formula proposed by the National Center for Emission Management (2015a):

$\mathrm{E}=\mathrm{B} * \mathrm{~W}$

where: 
E- emission of substances,

$\mathrm{B}$ - fuel consumption,

W - emission factor per unit of consumed fuel.

The problem, however, is the lack of sufficient data that allows for calculation of the amount of pollutant emissions from the household sector in a reliable and unambiguous manner. Installations working in individual households are not registered and fuel sales are also not subject to any form of monitoring. Therefore, it is difficult to determine the type of furnaces working in a given area and the type of fuel that is burnt. Therefore, the exact number of houses fired with a specific energy material cannot be given. It is possible to make estimated calculations based on data on construction (Central Statistical Office 2016), consumption of particular fuels by households (Central Statistical Office 2016a), and emission indicators for particular fuels (Table 2).

In Poland, coal is a basic raw material used to generate energy and heating homes. One household consumes an average of 4.5 metric tons of this resource; it is a hypothetical assumption calculated on the basis of Table 1: the number of buildings in 2011 was $2,176,357$, while consumption of coal by households reached the value of 9,750,000 metric tons. Thus, an individual household accounts for approximately 4.5 metric tons of hard coal per year.

If this raw material is burnt in a boiler with low combustion power, the combustion process is accompanied by the following emission of pollutants:

$\mathrm{E}_{\mathrm{NOx}}=2,200 * 4.5=9,900 \mathrm{~g}$

$\mathrm{E}_{\mathrm{CO}}=45,000 * 4.5=202,500 \mathrm{~g}$

$\mathrm{E}_{\mathrm{CO} 2}=185,000 * 4.5=82,500 \mathrm{~g}$

Ebenzo[a]pyrene $=14 * 4.5=63 \mathrm{~g}$

Since not all residential buildings are fired with coal, the above example is only intended to illustrate the importance of individual households in the fight to improve air quality.

Table 2: Emission indicators of individual pollutants for boilers below $0.5 \mathrm{MW}$

\begin{tabular}{|l|c|c|c|c|}
\multirow{2}{*}{ Kind of fuel } & \multicolumn{1}{c}{$\begin{array}{c}\text { hard coal } \\
{[\mathrm{g} / \mathbf{M g}]}\end{array}$} & $\begin{array}{c}\text { coke } \\
{[\mathrm{g} / \mathbf{M g}]}\end{array}$ & $\begin{array}{c}\text { wood } \\
{[\mathrm{g} / \mathbf{M g}]}\end{array}$ & $\begin{array}{c}\text { natural gas } \\
{[\mathrm{g} / \mathrm{m} 3]}\end{array}$ \\
\hline $\mathbf{N o}_{\mathbf{x}}$ & 2,200 & 500 & 1,000 & 1.52 \\
\hline $\mathrm{CO}$ & 45,000 & 25,000 & 26,000 & 0 \\
\hline $\mathrm{CO}_{2}$ & 185,000 & $2,360,000$ & $1,200,000$ & 2,000 \\
\hline benzo[a]pyrene & 14 & 0,1 & - & - \\
\hline
\end{tabular}

\section{Changing Methodology of Project Management Related to Air Quality to Project Management}

Issues related to air quality and activities aimed at improving its quality are multisectoral and should be considered at the stage of shaping the country's economic development strategy. Currently, the superior institution shaping legislation concerning air protection is the Ministry of Environment. By means of administrative orders, this body determines the permissible concentrations of pollutants in the air. The Inspectorates for Environmental Protection are responsible for monitoring and controlling air quality. The institution that finances activities related to air quality improvement is the Fund for 
Environmental Protection and Water Management. However, these are not the only institutions whose aim is to implement atmosphere protection programs. Projects concerning ecology and environmental protection are one of the main areas of interest of non-governmental organizations.

There are numerous organizations of public interest in this field that implement projects financed from budget and off-budget funds. Despite numerous projects and institutions implementing such programs, public awareness in terms of air quality is still low. This results in non-ecological activities such as a choice of not environmentally unfriendly source of home heating or energy waste. That is why, it is extremely important to involve the public in projects aimed at improving air quality. Society should act as a stakeholder of projects that would have the real impact.

The table below (Table 3) contains the features of traditional project management and the model recommended by the Project Management Institute (2015). The traditional model is the most common model in the government administration. Projects implemented this way involve only specialists selected by the management; they achieve specific goals within a specific period of time. Public participation in these projects is usually limited to the role of a training participant, a beneficiary of a grant or a recipient of a service. The involvement of society in the course of the project is not possible in this approach, even participants of a project have little opportunity to make decisions on the course of the project.

Table 3: Characteristics of selected models of project management

\begin{tabular}{|l|l|}
\hline PMI model & Traditional model \\
\hline specialties & $\rightarrow$ one specific superior \\
$\rightarrow$ team created for duration and & $\rightarrow$ employees grouped by specialization \\
implementation of a project & $\rightarrow$ usually low employee involvement in a project/ \\
$\rightarrow$ large autonomy of the project manager & combination of many functions in various projects \\
$\rightarrow$ full involvement of all project members & $\begin{array}{l}\rightarrow \text { each department performs its tasks independently } \\
\rightarrow \text { impact of stakeholders on a project }\end{array}$
\end{tabular}

PMI methodology is widely employed in the business world where, apart from the implementation of the project and set goals, the profit and the development of the enterprise also matter. Distinctive features of this approach to project management are building of a team whose members have diverse competence and possibility of involving all participants in a project. Since the improvement of air quality is only possible as a result of taking a wide range of legislative, administrative, educational, technological, and economic actions, it is necessary to discontinue employing the traditional model of project management of air quality improvement projects and replace it with projects of wider possibilities, managed according to methodology enabling involvement of society in projects as well as of a wider group of specialists with varied competence.

Finland is an example of a country in which project management models were applied to enable public participation in projects. It is the involvement of society in the management and environmental processes that made Finland, following Switzerland, to top of the list of countries with the highest index of sustainable development (World Economic Forum 2013). The main goal of the Finnish administration in terms of environmental protection is to provide a safe and attractive environment for life. The basis for actions is public 
participation in decision making. It is possible thanks to easy access to public information, increasing the importance of local administration and democratic rules of making decisions regarding environmental protection (Jiang L., Xianglin H., Erkki H. 2015). Also Poland, like other EU members European Commission (2010a), European Commission (2010b) has committed to implement sustainable development policies by integrating activities in the economic, social and environmental areas for the benefit of future generations (Mempel-Śnieżyk 2014).

\section{Summary and Conclusions}

Until now, the year 1988 was considered as a reference in determining the level of emission reduction. In Poland, since that period, there has been a significant reduction in greenhouse gas emissions - by almost $20 \%$. This reduction was associated with a rapid decline in industrial production in the period of political changes and the economic slowdown of the 1990s. Poland is still in a group of countries with the most emissionintensive economy. This is mainly due to the fact that the energy sector is based on coalfired power plants. The reason for poor quality of air in Polish cities is also emissions from the household sector. Poland deals with the phenomenon of a decrease in the amount of pollution emitted by industry and at the same time an increase in emissions from residential buildings, the number of which is constantly growing, which means that new sources of emissions are constantly increasing.

Individual central heating installations in residential buildings have the largest share in total emissions of particulate matter as well as PM10 and PM2.5. Burning processes of fossil fuels, such as hard coal in furnaces, contribute to such a situation.

In case of total dust, $40.3 \%$ of pollution comes from non-industrial combustion processes, $50.4 \%$ of PM10 particulate matter and $51.2 \%$ of PM2.5 come from the non-industrial sector. A lot of this emission comes from individual home furnaces. It is not easy to assess accurately the share of the household sector in dust emissions as there are no registers of individual installations or sold energy materials. The Central Statistical Office (2016a) publishes data on general consumption of energy resources in the study entitled Fuel consumption and energy carriers in 2015; the presented data show that individual customers, in particular households, constitute a significant group among consumers of hard coal, natural gas and heat. In 2016 households consumed 9,750 thousand metric tons of hard coal; considerable consumption of coal by residential buildings means high emission of pollutants accompanying the combustion process. Therefore, creation of new buildings will lead to an increase in pollutant emissions. In addition, emission will take place in residential areas and thus will pose a direct threat to the health of residents of housing estates constituting large concentrations of central heating installations. According to data published by the Central Statistical Office (2016b), buildings in which there is one apartment- a building understood as a single-family building, currently constitute $74.1 \%$ of all residential buildings in cities; since 2002 there has been an increase from $70.4 \%$. Single-family houses also prevail in case of new buildings put into operation. This group comprises the largest number of newly built construction facilities both in cities and in rural areas. Single-family houses are the most often equipped with an individual source of heat, which is confirmed by the report published in 2016 by the Central Statistical Office 
entitled Fuel consumption and energy carriers in 2015 (Central Statistical Office 2016a). In residential buildings, the number of which in 2016 amounted to 5,542,565, independent installations of central heating are used in 3,940,647 buildings.

As the number of single-family houses, which are sources of uncontrolled emission of pollutants, mainly harmful to health of particulate matter, is still growing and due to the fact that the emission takes place directly in the places of residence of a large number of people, raising social awareness of residents is extremely important. Currently, it is the household sector in the cities that is responsible for a significant part of the emission of atmospheric pollution. For this reason, awareness of users of these installations about atmospheric pollution and its sources is extremely important. The research on knowledge concerning atmosphere protection among the residents of the city of Wroclaw indicates that this knowledge is good, but the main reasons for choosing a given method of heating are the lowest price of a given fuel and operating costs.

In view of the above data on pollutant emissions, single-family housing and public awareness, it is almost certain that projects aimed at improving air quality in Poland cannot be successfully implemented without involving the public. It is currently individual installations that are responsible for a large percentage of emissions of some of the pollutants. Therefore, it is necessary to change the approach to project management in the atmosphere protection sector and to adopt methodology allowing for real involvement of society. The application of existing methods consisting mainly in informing the public or issuing orders and prohibitions will result in the creation of dead letters.

\section{Acknowledgements}

I would like to thank Mr. Krystian Zakrzewski for his help to data collection.

\section{References}

European Commission (2010a). COM (2010) 2020 Europe 2020. A European strategy for smart, sustainable and inclusive growth, Brussels, 3.3.2010. Online available: http://ec.europa.eu/eu2020/pdf/COMPLET $\% 20$ EN $\% 20$ BARROSO $\% 20 \% 20 \% 20007 \% 20-020$ Europe $\% 202020 \% 20-\% 20$ EN $\% 20$ version.pdf.

European Commission, (2010b).Commission Staff Working Document accompanying the Commission Communication on Regional Policy contributing to smart growth in Europe 2020, http://eurlex.europa.eu/LexUriServ/LexUriServ.do?uri=CELEX:52010SC1183:EN:NOT.

Central Statistical Office (2016a). Fuel consumption and energy carriers. Department of Economic Statistics of the Central Statistical Office. Warsaw.

Central Statistical Office (2016b). Construction - the results of operations in 2015. Department of Economic Statistics of the Central Statistical Office. Warsaw.

Institute of Environmental Protection - National Research Institute, National Center for Balancing and Emission Management (2015a). National balance of emissions of $\mathrm{SO}_{2} \mathrm{NOx}, \mathrm{CO}, \mathrm{NH}_{3}, \mathrm{NMVOCs}$, dusts, heavy metals and POPs in the classification system SNAP and NFR; Basic report. Warsaw.

Institute of Environmental Protection - National Research Institute, National Center for Balancing and Emission Management (2015b). Emission indicators of pollutants s from fuel combustion boilers with nominal power up to 5MW. Warsaw.

Jiang L., Xianglin H., Erkki H. (2015). Public participation in environmental permitting: the Finish approach and its effects. Int. Journal Environment and Pollution, 57(1-2), 1-16.

Mempel-Śnieżyk, A. (2014). Networks and cooperation for sustainable development The role of local authorities and clusters in regional development and economic growth. European Journal of Sustainable Development (2014), 3, 3, 111-120. 
McKinsley \& Company (2009). Assessment of greenhouse gas emission reduction potential in Poland by 2030, $5-35$.

Pietras-Szewczyk M. (2017). Appraisement of geographic information systems as tool supporting energy management in the cities. Energy and Environment (28/4), 437-450.

Pietras M. (2012). Pietras M. Możliwości redukcji emisji zanieczyszczeń atmosferycznych przez zastosowanie kolektorów słonecznych na obszarze województwa dolnośląskiego. PhD Thesis, University of Wroclaw, Poland, 2012.

Project Management Institute (2015). A Guide to the Project Management Body of Knowledge (PMBOK Guide - Fifth Edition.)

World Economic Forum (2013). The Global Competitiveness Report 2012-2013. http://reports.weforum.org/global-competitiveness-report-2012-2013/ (21/03/2017).

Zwoździak, J., Paciorek, M., Bemka, A., Paciorek, M. (2017). Limitations of low emission from individual coal heating in Wroclaw in 2016-2020. Wroclaw.

Zakrzewski K. (2019). Awareness of residents of the city of Wroclaw about the sources of atmospheric pollution. Manuscript of a thesis, University of Lower Silesia, Poland. 